\title{
Anadolu Liselerinde İkinci Yabancı Dil Olarak Almanca Eğitimi: Batman İli Örneği
}

\author{
Umut BALCI ${ }^{1}$ \\ ${ }^{1}$ Doç. Dr., Batman Üniversitesi Turizm İsletmeciliği ve Otelcilik. Yükesekokulu, balci u@yahoo.de
}

DOI: http://dx.doi.org/10.14582/DUZGEF.757

\section{ÖZ}

Çalışmamızın amacı, Batman ili ve ilçelerindeki Anadolu liseleri ile ilgili öğretmen ve alt yapı yeterliliğini tespit etmektir. Bundan yola çıkarak bu çalışmada öncelikli olarak Batman ili ve ilçelerindeki Anadolu liselerinde görev yapan kadrolu ve sözleşmeli öğretmenlerin sayı olarak yeterliliği ayrıca eğitim ortamlarnnı yabancı dil eğitimi açısından uygunluğu tartışılmıştır. Anadolu liselerinde görev yapan müdürlere uyguladığımız anketten elde ettiğimiz verileri nitel araştırma yöntemlerinden biri olan ve araştırılan konu ile ilgili ayrıntılı bilgi toplayıp elde edilen bilgileri yorumlama üzerine dayanan betimsel araştırma modeline göre analiz ettik. Çalışmamızın sonucunda Batman ilindeki Anadolu liselerinin büyük bir kısmında kadrolu Almanca öğretmeni sıkıntısı yaşandığını, yöneticilerin kadrolu Almanca öğretmen açığını sözleşmeli öğretmenlerle kapatmaktan imtina ettiklerini ve dil eğitiminin temel faktörlerinden biri olan dil derslikleri veya dil laboratuvarının hiçbir okulda olmadığını gözlemledik.

Anahtar Kelimeler: Dil Eğitimi, Almanca, Anadolu Lisesi, İstihdam, Derslikler ve Donanım

\section{German Education as a Second Foreign Language in Anatolian High Schools: The Case of Batman}

\begin{abstract}
The aim of the study is to determine the sufficiency of teachers and infrastructure related to the Anatolian high schools in Batman city center and its districts (Batman). Thus, the number of permanent and contracted teachers working in Anatolian high schools in Batman and the appropriateness of their educational environments with regard to foreign language education were primarily discussed in this study. We analyzed the data, obtained from the questionnaire which were applied to the Anatolian high school principals, via descriptive research model that is one of the qualitative research methods based on the interpretation of the information obtained by gathering detailed information on the research subject. As a result of the study, we observed that a large part of the Anatolian high schools had a problem with the staff teaching German, and the principals avoid to fill the deficiency of German teachers with contracted teachers. In addition to these findings, language classrooms or language laboratories were not in any school.
\end{abstract}

Keywords: foreign language, German, Anatolian high school, employment, klassroom and equipment 


\section{GİRİ̧̧}

Milli Eğitim Bakanlı̆̆ı’nın 06.05.2010 tarihli “Genel Liselerin Anadolu Liselerine Dönüştürülmesi” başlıklı genelgesiyle (Milli Eğitim Bakanlığı [MEB], 2010) Türkiye'deki düz liseler aşamalı olarak Anadolu liselerine dönüştürülmeye başlanmıştır. Bu dönüşüm çalışmaları neticesinde Milli Eğitim Bakanlığı 7 Eylül 2013 tarihli Resmi Gazete'de yeni “Millî Eğitim Bakanlı̆ğ Ortaöğretim Kurumları Yönetmeliğ̣”ni (MEB, 2013) yayınlamıştır. $\mathrm{Bu}$ yönetmeliğin Madde 10 (2) a bendinde, ortaokullardaki yabanc1 dil eğitimine yönelik:

Yabanc dil dersinde ögrencilere dinleme, konusma, okuma, yazma becerileri yönünden yabancı dil programinda belirlenen kazanmmlara uygun olarak eğitim verilir. Haftallk ders çizelgesinde belirtilen ders saatinin becerilere göre dağzllmu, hažrllk sinfi yabancı dil zümre ögretmenlerince belirlenir (MEB Ortä̈ğretim Kurumlar Yönetmelï̆̈̈,(2013).md .10)

şeklinde bir açıklama yapılmıştır. Yönetmeliğin yabancı dil eğitimi ile bağlantılı tüm maddelerinde temel amaç öğrencilerde dört temel becerinin (okuma, yazma, dinleme, konuşma) geliştirilmesini ve öğrencilerin öğrendikleri dilde kendilerini hem yazılı hem de sözlü olarak iyi ifade edebilmelerini sağlamaktır.

Daha iyi iş imkanlarına sahip olmak, ya da sosyal statü olarak yükselmek, İngilizce bilmek ile eş anlamlı görülmeye (Özdemir, 2006) başlandığından dolayı yabancı dil olarak İngilizce dersi liselerde uzun yıllar birinci yabancı dil olarak yerini almışve bu durum ikinci yabancı dil eğitiminin ihmal edilmesine neden olmuştur (Çetintaş \& Genç, 2001; Arak, 2010; Ak1llılar, 2013; Koçak, 2014). 2012-2013 eğitim yllı itibariyle yürürlüğe giren ve kamuoyunda $4+4+4$ olarak bilinen eğitim kanunu ile birlikte birinci yabancı dil öğrenme yaşı geriye çekilmiştir. Böylelikle ilkokul 2. sınıftan başlayan birinci yabancı dil eğitimi (İngilizce) ortaokullardaki ikinci yabancı dil eğitiminin önünü açmıştır. Türkiye'de Almancanın ikinci yabancı dil olarak İngilizceden sonra yaygin olarak öğretilmesi dikkatlerin Almanca dil eğitimine yönelmesine vesile olmuştur (Bayyurt, 2012; Akıllılar, 2013). Avrupa Konseyi’nin 2001 yllında yürürlüğe koyduğu “Avrupa Ortak Dil Kriterleri Çerçeve Programı"nda vurgulanan “çok dillilik” (Telc, 2013) ve “Avrupa Dil Portfolyosu" (Mirici, 2000) kavramları da Türkiye'deki ikinci hatta üçüncü yabancı dil eğitimine bakış açısını olumlu yönde değiştirmiş, bu doğrultuda eğitim çalışmalarının yürütülmesini sağlamıştır.

Millî Eğitim Bakanlığ1 Ortaöğretim Kurumları Yönetmeliği ve 2012-2013 eğitim yllında yürürlüğe giren yeni eğitim kanunu bağlamında yeniden düzenlenen ortaöğretim yabancı dil eğitimi, yukarıda da anlatıldığı gibi, ikinci yabancı dil olarak Almancanın Türkiye'deki algısını değiştirmiş, böylelikle Almanca Anadolu liselerinde zorunlu yabancı dil olarak okutulmaya başlanmıştır. Çalışmamızın amacı, yeni eğitim kanunu bağlamında yeniden düzenlenen ortaöğretim yabancı dil eğitimi çerçevesinde Batman ili ve ilçelerindeki Anadolu liseleri ile ilgili öğretmen ve alt yapı yeterliliğini tespit etmektir. Bundan yola çıkarak bu çalışsmada öncelikli olarak Batman ili ve ilçelerindeki Anadolu liselerinde görev yapan kadrolu ve sözleşmeli öğretmenlerin sayı olarak yeterliliği, öğrenci başına düşen öğretmen sayısı, devamında ise yeni eğitim kanunun öngördüğü ve kanunun 97 (1) maddesinde dile getirdiği eğitim ortamlarnın yabanc1 dil eğitimi açısından yeterliliği tartışılmış ve daha uygun dil eğitim ortamları için öneriler getirilmiştir. 


\section{YÖNTEM}

Bu çalışmada 2015-2016 eğitim öğretim yllında Batman ili ve ilçelerindeki Anadolu liselerinde müdürlük görevini yürüten eğitim idarecilerinin Almancanın Anadolu liselerindeki konumuna, Almanca öğretmenlerinin sayısal yeterliliğine ve yönettikleri okulların dil eğitimi açısından fiziki şartların durumuna yönelik görüşlerinin belirlenmesi amaçlanmıştır. Bu doğrultuda hazırlanan anket soruları nitel araştırma yöntemlerinden biri olan ve araştırılan konu ile ilgili ayrıntılı bilgi toplayıp elde edilen bilgileri yorumlama (Hermeneutik) üzerine dayanan (Bal, 2016) betimsel araştırma modeline göre analiz edilmiştir.

\subsection{Evren ve Örneklem}

Araştırmanın evrenin Batman il ve ilçelerindeki Anadolu liselerinde görev yapan müdürler oluşturmaktadır. Evren gurubu Batman merkezde bulunan 24 Anadolu Lisesi, Gercüş ve Kozluk ilçelerinden 3er, Beşiri ve Sason ilçelerinden 2şer ve Hasankeyf ilçesinden 1 Anadolu lisesi olmak üzere toplamda 35 Anadolu lisesinden oluşmaktadır. Batman ili genelinde 35 tane Anadolu lisesinin bulunması, fakat bunlardan 23 lisenin anketimize katılmasından dolayı çalışmamızın örneklemini Batman il ve ilçelerindeki Anadolu liselerinde görev yapan 23 Anadolu lisesi oluşturmaktadır. Örneklem gurubumuz, "bu, burada oluyorsa, başka benzer durumlarda kesinlikle olur" veya tam tersi bir durumu ifade eden kritik durum örneklemi (Yıldıım \& Şimşek, 2013) olarak değerlendirilmektedir.

\subsection{Verilerin Toplanmas1}

Veri toplama aracı olarak 10 sorudan oluşan bir anket kullanılmıştır. Soruların ilk dördü okullarda mevcut Almanca öğretmenlerinin yeterliliğini tespit etmeye yöneliktir. Beşinci soruda Almanca dersini alan şube sayısı ve altıncı soruda Almanca dersini alan öğrenci sayısı sorulmuştur. Yedinci soruda ise boş geçen almanca derslerinin olup olmadığı sorulmuştur. Bu sorulardan yola çıkarak öğretmen başına düşen öğrenci sayısının hesaplanması ve bunun sonucunda durum tespitinin yapılması amaçlanmıştır. Sekiz ve dokuzuncu sorular okulda sağlıklı bir dil eğitiminin verilebilmesi açısından fiziki şartların yeterliliğini ölçmeye yöneliktir. Son soruda ise okul yöneticisinden, okulundaki dil eğitimine dair ek ifadeleri varsa eklemesi istenmiştir. Ankete katılanların çok zamanını almamak ve böylelikle anketlerin dönüt oranını yüksek tutmak amacıyla çalışmamızın temel çıkış noktasını ilgilendiren kısa ve net sorular sorulmuştur. Araştırmaya kapsam ve derinlik kazandırmak adına da (Arıkan, 2013, s.101) ankete farklı tip sorular da dahil edilmiştir. Anketler 2015-2016 eğitim öğretim ylında uygulanmış ve toplanmıştır.

\subsection{Verilerin Analizi}

Anket soruları nitel araştırma yöntemlerinden biri olan betimsel araştırma modeline göre analiz edilmiştir.Verilerimizin analizi anketimizde yer alan soruların gruplandırılmasıyla ortaya çıkan iki ana başlık altında ele alınmıştır, bunlar: Öğretmen istihdam yeterlilĭgi ve derslikler ve donanumdır.

\section{BULGULAR}

\section{1 Öğretmen İstihdam Yeterliliği}

Türk eğitim sisteminde yllarca üzerinde önemle durulan fakat hedeflenen başarıya bir türlü ulaşılamayan ana sorunsal istihdamdır (Özsoy, 2015). Yükseköğretimin çok çeşitli bölümlerinde eğitimi görüp mezun olan öğretmen adaylarının da temel sorunsalını oluşturan istihdam konusu Milli Eğitim Bakanlığının çalışmaları doğrultusunda sorun olmaktan çıkarılmaya çalışılmakta, mezun olan öğrencilerin 
ise Anadolu liselerine yerleştirilmesi çalışmalarına devam edilmektedir. Bu doğrultuda, lisans mezunu öğrencilerin Milli Eğitim Bakanlı̆̆ tarafindan ortaöğretim kurumlarına öğretmen olarak atanabilmesi için öncelikli olarak KPSS sınavına girme zorunluluğu vardır. Genel kültür, genel yetenek ve eğitim bilimleri testlerinden oluşan KPSS sınavının yanı sıra bazı branşlarda (Türk Dili ve Edebiyatı, Matematik, Almanca, İngilizce, Sosyal Bilimler, Fen Bilgisi vs.) alan bilgisini ölçen ÖABT ${ }^{1}$ sınavına da girmek gerekmektedir (MEB, 2013).

Öğretmen istihdamı MEB tarafından iki farklı şekilde uygulanmaktadır. Bunlar kadrolu ve sözleşmeli öğretmen istihdamıdır. Kadrolu atamalar yukarıda dile getirdiğimiz KPSS sınav sonucuna göre yapılmaktadır. Öğretmen istihdamı, özellikle kadrolu istihdam her alanda olduğu gibi arz ve talep dengesi içinde değerlendirilmesi gereken bir olgudur (Aydın ve diğ, 2014). Arz ve talep doğrultusunda yapılacak uygun planlamalar sayesinde lisans eğitimlerini tamamlayan öğrencilerin mesleki hayata daha kolay adım atmaları (Nartgün, 2008) ve bilgi birikimlerini yeni nesillere aktarmaları kolaylaşacaktır.

Sözleşmeli öğretmen istihdamı ise öğretmenlerin yasal olarak "diğer kamu görevlileri” statüsünde değerlendirildiği; atanmaya esas sözleşmenin açık olmadığı; öğretmenlerin kadrolu olarak atanmış olmayı tercih ettikleri; iş güvenceleri olmadığ1; kadrolu öğretmenlerin sahip olduğu bazı hakların olmadığı bir atama yöntemi olarak bilinmektedir (Gündüz, 2008). Bu bilgilerden hareketle, sözleşmeli statüsünde çalışan öğretmenlerin mesleki kaygılarını arttıran temel faktör iş güvencelerinin olmaması, dolayısıyla her an işsiz kalma ihtimali ile yüzleşme sorunu şeklinde ortaya çıkmaktadır. Bu da sözleşmeli öğretmenlerin mesleki adaptasyonunu da olumsuz (Demir \& Karadeniz, 2010) etkileyen bir faktördür.

İstihdam konusundaki arz talep sorunsalından hareketle, ÖABT Almanca sinavina giren aday öğretmen sayısı ile kadrolu atanma sayısını içeren Tablo $1^{2}$ incelendiğinde, 2013 y1lındaki atanma sayısı aday öğretmenlere umut olmuş, sınava giren aday sayısı sonraki yıllarda ciddi bir şekilde artış göstermiştir. Atanma sayısında ise tersi bir durum gözlenmiş, sınava giren aday sayısı bağlamında atanma oranı 2013 yllında \%16 iken, bu oran 2014’te \%4,3 ve 2015’te \%4,5 oranında gözlemlenmiştir. Bu oranlar istihdam konusunda ciddi bir yetersizliğin ortaya çıtı̆̆ını gözler önüne sermektedir.

Tablo 1. ÖABT Almanca sinav durum tablosu

\begin{tabular}{cccc}
\hline Test Adı & Y1 & Aday Sayıs & Atanma Sayıs \\
\hline Yabanc1 Dil Almanca & 2013 & 2757 & 446 \\
\hline Yabanc1 Dil Almanca & 2014 & 3880 & 167 \\
\hline Yabanc1 Dil Almanca & 2015 & 4287 & 194 \\
\hline
\end{tabular}

Batman il ve ilçelerindeki Anadolu liselerinde görev yapan müdürlere uyguladığımız anket de yukarıda dile getirdiğimiz istihdam sorununa yönelik sorular içermekte ve müdürlerin bu konudaki görüşlerine yer vermektedir. İstihdama yönelik anket sorularımız şu şekildedir:

\footnotetext{
1 Öğretmenlik Alan Bilgisi Testi (ÖABT) Almanca ile ilgili içerik analizine yönelik çalışmalar daha önce yapılmış olup bunların arasında Demiryay ve Balcı'nın "Öğretmenler İçin Alan Bilgisi (ÖABT) Almanca Sınavına Yönelik Almanca Öğretmenliği Lisans Eğitiminin Yeterlilik Sorunu" ile Maden ve Aykut'un "Ölçme Seçme ve Yerleştirme Merkezi (ÖSYM) Tarafindan Hazırlanan, Uygulanan ve Değerlendirilen Almanca Yabancı Dil Sınavlarında Yer Alan Bağlaçlara İlişkin Bir Araştırma” başlıklı makaleleri anılan sınav ve içerikleri ile ilgili detaylı analiz içermektedir.
}

2 Tablodaki verilere ÖSYM’nin http://www.osym.gov.tr/belge/1-12668/gecmis-yillardaki-sinavlara-ait-sayisal-bilgiler.html linkinden ulaşılmıştır (Erişim Tarihi: 28.04.2016). 
1. Okulunuzda kadrolu kaç Almanca öğretmeni mevcuttur?

2. Mevcut kadrolu Almanca öğretmenleri eğitim faaliyetlerinin eksiksiz yürütülmesi açısından yeterli mi?

3. Kadrolu Almanca öğretmenleriniz yetersiz ise, Milli Ĕ̆itim Bakanlı̆̆ı'ndan (MEB) öğretmen talebinde bulunuyor musunuz?

4. Sözleşmeli kaç tane Almanca öğretmeni çalıştırmaktasınız?

Anketimize katılan 4 İmam Hatip Anadolu Lisesi müdürü $(\% 17,3)$ müfredatları gereği okullarında yabancı dil olarak Almanca dersinin mevcut olmadığını dile getirmişlerdir. İmam Hatip Anadolu liselerinde ağırlıklı olarak İngilizce dil eğitimi verilmektedir. Dolayısıyla bu liseler Milli Eğitim Bakanlı̆̆ı'ndan Almanca öğretmeni talebinde bulunmamakta, sözleşmeli öğretmen istihdam etme ihtiyacı duymamaktadır.

Müfredatlarında yabancı dil olarak Almanca dersi olmasına rağmen kadrolu öğretmeni olmayan 3 Anadolu Lisesi (\%13) tespit edilmiştir. Bu üç lisede de Almanca öğretmeni olmadığından dolayı Milli Eğitim Bakanlı̆̆ı’ndan Almanca öğretmeni talep edilmesine rağmen henüz kadrolu Almanca öğretmeni ataması yapılmamıştır. Bahsi geçen 3 lise de, Sözleşmeli kaç tane Almanca ögretmeni çalıștırmaktasımız? sorusuna herhangi bir yanıt vermemiştir.

Anketimize katılan 6 tane Anadolu Lisesinin (\%26) birer kadrolu Almanca öğretmenine sahip olduğu, bunlardan dört tanesinin bu sayıyı yeterli gördüğü, iki tansinin ise bu sayıyı yetersiz gördüğü tespit edilmiştir. Kadrolu öğretmen sayısını yeterli gören 4 lise dahil olmak üzere, birer kadrolu öğretmeni olan tüm liselerin Milli Eğitim Bakanlığı’ndan Almanca öğretmeni kadrosu talep ettikleri tespit edilmiştir. Bu liselerde sözleşmeli Almanca öğretmeninin istihdam edilmediği de gözlemlenmiştir.

Batman ilinde mevcut 9 Anadolu lisesinde (\%39.1) 2şer adet kadrolu Almanca öğretmeni tespit edilmiş, bu liselerden 6 tanesi mevcut 2 Almanca öğretmenini yeterli görüp artı kadro talebinde bulunmazken, 3 lise ise 2 Almanca öğretmenini yetersiz görmekte ve Milli Eğitim Bakanlı̆̆1'ndan Almanca öğretmni kadrosu talep etmektedir. Bu liselerin hiç birinde sözleşmeli öğretmen istihdamı olmadığ1 da tespit edilmiştir.

3 kadrolu Almanca öğretmenine sahip bir Anadolu lisesinde ise (\%4.3) kadrolu öğretmen yetersizliği olduğu, Milli Eğitim Bakanlı̆̆ı'ndan kadrolu Almanca öğretmeni talebinde bulunulduğu, fakat buna rağmen sözleşmeli öğretmen istihdam edilmediği tespit edilmiştir.

Kadrolu öğretmen yeterliliğini ölçmek için de liselerdeki Almanca dersleriyle bağlantılı olarak aşağıdaki üç soruya anketimizde yer verilmiştir:

1. Toplam kaç şubede Almanca dersleri verilmektedir?

2. Almanca dersini alan toplam öğrenci sayınız kaçtır?

3. Öğretmen (kadrolu veya kadrosuz) yetersizliğinden dolayı boş geçen Almanca dersleri var mi?

Çalışmamız bağlamında ele aldığımız 23 Anadolu Lisesinin 2 tanesinde 3er şubede Almanca dil eğitimi verilmektedir. Bu sayının azlığı bazı liselerde ikinci yabancı dil eğitiminde Arapçaya dönülmesidir. Bu liselerde boş geçen Almanca dersinin olmadı̆̆ı gözlemlenmiştir. 21 Anadolu lisesinin tüm şubelerinde 
ise Almanca dil eğitimi dersi verildiği ve bunların arasında sedece iki lisede boş geçen Almanca dil dersinin olduğu görülmüştür.

\subsection{Derslikler ve Donanım:}

Yabancı dil eğitiminde derslikler (sınıf) ve dersliklerin sahip olduğu donanım (akıllı tahta, projeksiyon, ses sistemi, bilgisayar vs.) önemli rol oynamaktadır. Dil eğitiminde özellikle çok yönlü aktivitelere ağırlık verilmesi bu önemi arttırmaktadır. Dolayısıyla dil öğretimine yönelik aktivitelerin amacına ulaşabilmesi için teknik açıdan yeterince donanımlı bir okula ihtiyaç vardır (Kırmızı, 2010). Dört temel beceri bağlamında düşünüldüğünde, Özellikle eğitimleri sırasında dilini öğrendikleri ülkeyi ziyaret etme şansı bulamayan öğrenciler için dinleme becerisini geliştirmek zorlaşmaktadır (Özbay, 2005). Bu zorluğu en aza indirmenin ilk koşulu dil eğitiminde öğrencilere uygun yöntem ve teknikler gelştirmenin yanı sıra (Balc1, 1993) dinlemeye yönelik aktiviteleri arttırmak ve bu aktiviteleri bilgisayar destekli yürütmektir. Bayrak da (2013) çalışmasında bilgisayar destekli ve internet kullanımına yer veren Almanca dil eğitimini ele almış ve bu tarz bir eğitim modelinin öğrencilerin ilgi ve isteklerini artırı̆ı̆̆ını dile getirmiştir. Korkmazer ve Yaprak da (2014) benzer şekilde dil eğitiminde internet kullanımının önemine vurgu yapmış, dil eğitimi odaklı internet kullanımının öğretmenler tarafindan öğrencilere önerilmesi gerektiğini belirtmiştir. Bu açıdan ele alındığında ise dil dersliklerinde ayrıca akıllı tahta kullanımı da zorunlu hale gelmektedir (Yücel, Göçerler \& Demir, 2015). Çünkü öğrenciler, gerek bilgisayar ortamında gerekse sınıf içi ortamda basılı malzemeleri kullanarak hazırladıkları materyalleri akıllı tahta sayesinde sınıftaki tüm öğrencilerin rahatlıkla görebileceği şekilde sunabilme ve gelen eleştiriler doğrultusunda bu materyaller üzerinde değişiklik yapabilme olanağına sahip olmaktadır.

Yabancı dil eğitiminde ön plana çıkan öğretim tekniklerinin biri de drama (oyun) yoluyla öğrenme ve öğretme modelidir. Drama yoluyla dil eğitimi yapılabilmesinin temel şartı dersliklerin dramatizasyona uygunluğudur. Drama da önemli olan öğrencinin keşfederek öğrenmesi ve buna bağlı olarak konu bağlamındaki yaratıcılığıdır. Dolayısıyla, Kırmızı’nın (2012) da ifade ettiği gibi, öğrencilerin sıra dışı fikirler üreterek yeni teknolojilere zemin hazırlaması için onların yaratıcı ve eleştirel düşünme becerilerini artırmalarına yardımcı olunmalıdır. Bu yüzden öğrencilerin sıraları ile tahta arasında, öğrencilerin aktivitelerini rahatlıkla sergileyebilmeleri için belli bir boşluk bırakılmalı ve bu alan öğrencilerin kullanımına sunulmalıdır.

Sınıf içi düzenin bir diğer önemli noktası da öğrenci masalarının boyutu ve dizilişidir. Masa boyutları öğrencilerin plakat vb. materyalleri hazırlamaları açısından uygun genişlikte olmalı, masa düzeninin düşünmeyi destekler, öğrencilerin birbirleriyle olan iletişimini kolaylaştıran bir biçimde tasarlanması ve öğretimin de bu doğrultuda yapılması gerekmektedir. $\mathrm{U}$ ve ya $\mathrm{V}$ şeklinde tasarlanmış bir oturma düzeni hem öğrencilerin kendi aralarındaki hem de öğretmenleriyle olan iletişimlerini kolaylaştırmaktadır. Geleneksel oturma düzeninin benimsendiği sınıflar, etkili bir iletişimin sağlanması için kesinlikle uygun değildir, tersine öğretmen merkezli dil eğitimi için uygundur. Tek gruplu ve çok gruplu yerleşim düzenleri ise yabancı dil sınıflarındaki iletişim ve grup çalışmaları açısından daha uygundur çünkü bu sınıflarda öğrenciler U veya V şeklinde ya da gruplar halinde oturmaktadırlar (Işık, 2006, Akt. Dellal \& Çınar, 2011 ).

Yukarıda dile getirdiğimiz bilgiler ışığında, yabancı dil dersinin sağlıklı bir şekilde yürütülebilmesi için Özetle; 
- Dersliklerde akıllı tahta, projeksiyon, ses sistemi, bilgisayar gibi teknoloji malzemelerinin bulunmasi gerekmektedir.

- Dersliklerde internet bağlantısının olması gerekmektedir.

- Öğrenci masaları uygulamalı bir şekilde ders materyali hazırlanabilmesi için geniş olmalidir.

- Öğrencilerin birbirleriyle yüzyüze iletişim kurabilmeleri için masaların U ve ya V şeklinde dizilmesi gerekmektedir.

- Sınıfin drama yollu öğrenim ve öğretim için uygun olması ve tahta önünün geniş olması gerekmektedir.

Batman il ve ilçelerindeki Anadolu liselerinde görev yapan müdürlere uyguladığımız anket çerçevesinde mevcut liselerin dersliklerinin yabancı dil eğitimine uygunlukları ve donanım açısından yeterlilikleri ölçülmüştür. Bu bağlamda dersliklerle ilgili olarak anketimizde iki soru yer almıştır:

1. Okulunuzda dil laboratuvarlar1 var mi?

2. Okulunuzun dil eğitimi için yeterli alt yapıya sahip olduğunu düşünüyor musunuz?

Aketimize katılan 23 Anadolu Lisesinin hiç birinde dil laboratuvarının olmadığı belirlenmiştir. 4 temel becerinin öğrencilere eksiksiz bir şekilde aktarılabilmesi için dil eğitiminin olmazsa olmazlarından biri kabul edilen laboratuvarların Anadolu Liseleride olmaması tespit edilen en büyük eksiklik olarak karşımıza ç1kmaktadır.

Anadolu liselerinin dil eğitimi için yeterli alt yapıya sahip olup olmadığını ölçen sorumuza ise 6 yeterli $(\% 26,08), 17$ yetersiz $(\% 73,91)$ cevap verilmiştir. Dil eğitimi alt yapısı için yeterli cevabı veren 6 lisede ise çıkış noktasının bilgisayar ve yansı kullanımı olduğu tespit edilmiştir. Oyasaki dersliklerdeki oturma düzeninden, sıra sayısına ve sahne şekline kadar bir çok etmenin bu doğrultuda göz önünde bulundurulmasi gerekmektedir.

Anketimizin son sorusu ise açık uçlu olup müdürlere mevcut dil eğitimi ile ilgili görüş ve önerileri sorulmuştur. Nitekim okul müdürleri dil eğitimi ile ilgili sorun ve sorunlara çözüm önerisi şeklinde çeşitli görüşlerini dile getirmişlerdir:

- Almanca dersleri İngilizce öğretmenlerine verildiğinden dolayı istenen verim elde edilememektedir. Almanca derslerin Almanca öğretmenleri tarafindan anlatılması verimliliği arttıracaktır.

- İlkokul 2. veya 3. sınıftan itibaren Almanca eğitimine bağlanmalıdır. 5. sınıfta Almanca hazırlık okultulmalıdır. Gramer eğitiminden çok, şark1, oyun, diyalog ve simülasyonlar kullanılarak dil öğretilmelidir. Çocuklar keyif alarak ders işlemeli, eğitimde teknolojiden faydalanılmalıdır. İnternet ve etkileşimli tahtalar aktif kullanılmalıdır.

- Öğretmen ihtiyac1 2 yıldır mevcuttur. Sözleşmeli öğretmenlerin uzun süreli devamlllğ̆ olmadığ için tercih edilmiyor.

- MEB ders kitabı göndermiyor, Özel basım kitaplar da çok pahalı olduğundan dolayı kaynak sıkıntısı yaşanmaktadır.

- Ders kitapları hem yetersiz, hem de içerik öğrencilere hitap etmemektedir. Haftalık ders sayıs1 da yetersizdir.

- Almanca eğitimi ortaokulda başlamalı, yeterli sayıda kadrolu öğretmen atanmalıdır. Okullarda dil laboratuvarlarının olmaması büyük bir eksiklik. 
- Okul alt yapısı oluşturulmalıdır. Öğrencilere yurt dışı olanağı ve deneyimi kazandirilmalıdır.

- Derslerin zevkli ve verimli olması için Milli Eğitim Bakanlığı’nın dil eğitimi ile ilgili yeterli materyal göndermesi gerekmektedir.

- Sınav odaklı sistemde dil eğitimi zorlaşmaktadır. Sınıflarda okutulan derslerin fazlalığı dil eğitimine olan ilgiyi azaltmaktadır.

- Derslerde pratiğe ağırlık verilmelidir. Yurt dışı gezileri düzenlenmelidir.

\section{TARTIŞMA ve SONUÇ}

Batman ili ve ilçelerindeki Anadolu liseleri ile ilgili öğretmen ve alt yap1 yeterliliğini tespit etmek amacıyla hazırladığımız çalışmada Anadolu liselerindeki yabancı dil olarak Almanca eğitimini öğretmen istihdam yeterliliği ve derslikler ve donanım olmak üzere iki açıdan ele aldık. Araştırmamız bağlamında aşağıdaki bulgulara ulaşılmışır:

Batman ili Anadolu liselerinin büyük bir kısmında kadrolu Almanca öğretmeni sıkıntıs1 yaşanmaktadır. Mevcut liselerin \%30.4'ünde tek bir kadrolu Almanca öğretmeni yokken, \%26'sında 1, \%39.1'inde 2 ve \%4.3'ünde 3 Almanca öğretmeni mevcuttur. Liselerin \%43'ü kadrolu öğretmen sayısını yeterli görmesine rağmen \%89.9’u Milli Eğitim Bakanlı̆̆’’ndan kadrolu Almanca öğretmeni talep etmekte, fakat talebin büyük kısmı karşıllanmamaktadır.

Kadrolu Almanca öğretmenine sahip olmayan liselerde Almanca dersleri kadrolu İngilizce öğretmenlerine devredilmekte, kağıt üstünde Almanca dil eğitimi aldığı ve bu dersten başarılı olduğu iddaa edilen öğrenci aslında sıfır dil becerisiyle mezun olmaktadır.

Türkiye'nin bir çok eğitim kurumunda kadrolu öğretmen açığ1 genellikle sözleşmeli istihdam ile karşılanmaya çalısıllmaktadır. Batman ili Anadolu liselerinde ise tersi bir durum gözlemlenmiş, yöneticilerin kadrolu Almanca öğretmen açı̆̆ını sözleşmeli öğretmenlerle kapatmaktan imtina ettikleri tespit edilmiştir. Mevcut liselerin sadece 2 tanesi (\%8.6) sözleşmeli öğretmen istihdam etmiş, kalan liselerin büyük kısmı

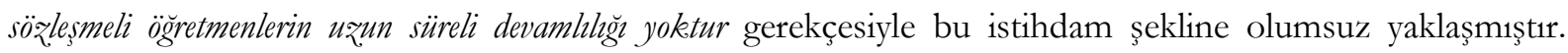
Sözleşmeli öğretmenlerin kadrolu öğretmenlerin sahip olduğu özlük haklarına sahip olmamaları, düşük ücret ödemeleri, iş güvencelerinin olmaması gibi etmenler onların mesleki kayg1 düzeylerini arttırmakta, dolayısıyla motivasyonlarını düşürmekte ve verimli ders işlemelerini engelemektedir.

Yabancı dil eğitiminin önemli faktörlerinden bir diğeri de mekandır, yani derslikler ve dersliklerde mevcut olması gereken donanımdır. Dil eğitiminde çok yönlü aktivitelere ağırlık verilmesi derslikler ve donanımın önemi daha da arttırmaktadır. Dersliklerdeki öğrenci masalarının uygulamalı bir şekilde ders materyali hazırlanabilmesi için yeterince geniş olması, bu masaların öğrencilerin birbirleriyle yüzyüze iletişim kurabilmeleri için $\mathrm{U}$ veya $\mathrm{V}$ şeklinde dizilmesi, drama yoluyla öğrenim ve öğretim gerçekleştirilebilmesi için tahta önünün geniş olması, bunların yanı sıra dersliklerde akıllı tahta, projeksiyon, ses sistemi, bilgisayar, internet gibi teknoloji malzemelerinin bulundurulması yabancı dil eğitimi verilecek dersliklerin olmazsa olmazlarıdır. Fakat yaptığımız araştırmada Batman ilindeki Anadolu liselerinin hepsinde (\%100’ünde İngilizce, \%69.5'inde Almanca) yabancı dil eğitimi verilmesine rağmen bu liselerin hiç birinde yukarıda saydığımı kriterlere uygun dil dersliği veya dil laboratuvarına rastlanamamıştır. Dolayısıyla, daha verimli dil eğitimi yapılabilmesi için Milli Eğitim Bakanlığı'nın liselerdeki dil dersliklerine yatırım yapması ve dil dersliklerini dil eğitimine uygun hale getirmesi gerekmektedir. 
Anadolu liselerde Almanca dil eğitimini olumsuz etkileyen faktörlerden bir tanesi de basılı kaynak sıkıntısıdır. Müdürlerin \%26’s1 Milli Eğitim Bakanlı̆̆ı tarafından Almanca dersiyle ilgili kaynakların gönderilmediğini, özel basım kitapların çok pahalı olduğunu, bunun sonucunda ise çok ciddi kaynak sıkıntısının yaşandığını dile getirmiştir.

\section{KAYNAKÇA}

Akıllılar, T. (2013). İkinci Yabancı Dil Olarak Almanca Öğreniminde Üstbilişsel Farkındalık. Uşak Üniversitesi Sosyal Bilimler Dergisi, Özel Say1, S. 275-285.

Arak, H. (2010). Almanca Öğreniminde ve Öğretiminde Köprü Dil İngilizceden Olumlu Transfer Örnekleri.TheJournal of International Social Research. Volume 3 / 10, s. 50-60.

Arıkan, R. (2013). Arastrma Yöntem ve Teknikleri. 3. bask1. Nobel Yayınlan1. Ankara.

Aydın, A., Sarıer, Y., Uysal, Ş., Aydoğdu-Özoğlu, E., \& Özer, F. (2014). Türkiye'de öğretmen istihdamı politikalarının değerlendirilmesi. Kuram ve Uygulamada Eğitim Yönetimi, 20(4), 397-420.

Bal, H. (2016). Nitel araștrma Yöntem ve Teknikleri. (Uygulamal-Örnekli). Sentez Yayınc1lı. Bursa.

Balc1, T. (1993). Türkiye'de Pek Uygulanmayan Yabanc1 Dil Öğretim Yöntemleri Üzerine. Öğretmen Dünyası, Nr. 158, s. 7-11.

Bayrak, A. (2013). Almanca Öğretmenliği Programı Öğrencilerinin Yabanc1 Dil Eğitiminde Bilgisayar ve İnternetin Kullanımına İlişkin Görüşleri. Anadolu Journal Of EducationalS ciences International, 3(1).

Bayyurt, Y. (2012). 4+ 4+ 4 Eğitim Sisteminde Erken Yaşta Yabanc1 Dil Eğitimi. In 1st Hacettepe UniversityForeign Language Education Workshop, s. 97-107.

Çetintaş, B. \& Genç, A. (2001). Eğitim Reformu Sonras1 Anadolu Liselerinde Yabanc1 Dil Öğretimi. Hacettepe Üniversitesi Ë̆gitim Fakültesi Dergisi, 20, S. 51-56.

Dellal, N. A. \& Çınar, S. (2011). Yabancı Dil Eğitiminde İletişimsel Yararcı Yaklaşım, Öğretmen Rolleri, Davranışları ve Sınıf İçi İletişim. Dil Dergisi, Sayı: 154, s. 21-36.

Demiryay, N. \& Balcı, U. (2014): Öğretmenler İçin Alan Bilgisi (ÖABT) Almanca Sınavına Yönelik Almanca Öğretmenliğgi Lisans Eğitiminin Yeterlilik Sorunu. Diyalog. 2014/2: 70-82.

Gündüz, B. (2008). Öğretmenlerin Sözleşmeli İstihdamı ve Durumlarına İlişkin Sözleşmeli Öğretmenlerin Görüşleri, The Journal of SAU Education Faculty, 16, s. 40-60.

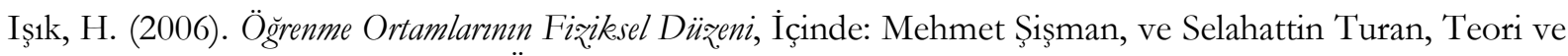
Uygulamada Sınıf Yönetimi, Öğreti Pegem A Yayıncılık, Ankara.

Karadeniz, Y. \& Demir, S. B. (2010). Sözleşmeli öğretmenlik uygulamasının değerlendirilmesi. Ondokuz Mayıs Üniversitesi Ë̈itim Fakëlltesi Dergisi, 29(2), 55-77.

Kırmızı, B. (2010). Anadolu Lisesi Öğrencilerinin Almanca Dersinin Öğretimine Yönelik Görüşlerinin Belirlenmesi. Selçu Üniversitesi Abmet Kelesoğgu Eğitim Fakültesi Dergisi Say1 29, Sayfa 197 -210.

Kırmızı, B. (2012). Almanca Derslerinde Altı Şapkalı Drama Tekniğinin Öğrencilerin Başarısına Etkisi. Adiyaman Üniversitesi Sosyal Bilimler Enstitïsü Dergisi, Say1 10, s. 265-290.

Koçak, M. (2014). “Toko-Demo” Adlı Almanca Ders Kitabında Ülke Bilgisi. 21. Yǚsyllda Eğitim Ve Toplum Eğitim Bilimleri Ve Sosyal Arastrumalar Dergisi,3(9). S.29-41.

Korkmazer, G. \& Yaprak, İ. H. (2014). Almanca Öğretmen Adaylarının Temel Dil Beceri Ve Alanlarına Yönelik İnternet Kullanma Alşskanlıkları Üzerine Bir Analiz. Electronic Turkish Studies, 9(6).s. 731-744.

Maden, S. S. \& Aykut, G. (2016). Ölçme Seçme ve Yerleştirme Merkezi (ÖSYM) Tarafindan Hazırlanan, Uygulanan ve Değerlendirilen Almanca Yabancı Dil Sınavlarında Yer Alan Bağlaçlara İlişkin Bir Araştırma. Diyalog 2016/1: 55-72.

MEB (2010). "Genel Liselerin Anadolu Liselerine Dönüştürülmesi” ile ilgili Genelge. ogm.meb.gov.tr/belgeler/genelge_2010_30.pdf (Erişim:14.02.2016). 
MEB (2013). Millî Eğitim Bakanlı̆g1 Ortaöğretim Kurumlar1 Yönetmeliği. http://www.resmigazete.gov.tr/eskiler/2013/09/20130907-4.htm (Erişim Tarihi: 16.02.2016).

Mirici, İ. H. (2000). European Language Portfolio: A toolfor a common language education policy in Europe. Journal of InterdisciplinaryEducation, 6 (1): 161-166.

Nartgün, S. Ş. (2008). Aday Öğretmenlerin Gözüyle Milli Eğitim Bakanlığına Bağlı Eğitim Kurumlarına Öğretmen Atama Esaslar1. Abant İ̌et Baysal Üniversitesi Eğitim Fakültesi Dergisi 8, (2), 47-58.

Özbay, M.(2005). Bir Dil Becerisi Olarak Dinleme Eğitimi, Ankara: Akçağ Yayınları.

Özdemir, A. E. (2006). Türkiye'de İngilizce Öğreniminin Yaygınlaşmasının Nedenleri. Mersin Üniversitesi Ë̈itim Fakültesi Dergisi, 2, (1), Haziran 2006, 28-35.

Özsoy, C. E. (2015). Mesleki Eğitim - İstihdam İlişkisi: Türkiye'de Mesleki Eğitimin Kalite ve KantitesiÜzerine Düşünceler. Electronic Journal of VocationalColleges- Aralık 2015 4. UMYOS Özel Say1s1, s. 173-181.

Telc (2013). Diller İ̧in Avrupa Ortak Öneriler Cerçevesi - Öğrenim, Öğretim Ve Değerlendirme. telcGmbH, Frankfurt/Main.

Yıldırım, A. \& Șimşek, H. (2013). Sosyal Bilimlerde Nitel Araștırma Yöntemleri. Genişletilmiş 9. Baskı. Seçkin Yayınları. Ankara.

Yücel, M. S.\&Göçerler, H.\& Demir, M. (2015). Interkulturelles Lernendurch den Whiteboardeinsatz als Zusatzmaterial. Humanitas-Uluslararası Sosyal Bilimler Dergisi, 3(5), 229-242.

\section{Citation Information}

Balcı, U. (2016) Anadolu Liselerinde İkinci Yabancı Dil Olarak Almanca Eğitimi: Batman İli Örneği. Dicle Üniversitesi Ziya Gökalp Eğitim Fakültesi Dergisi, 29, 346-355. 